\title{
Yenidoğan Konjonktivitleri
}

\author{
Oftalmia Neonatorum
}

\section{Özlem Bursalı, Erkan Çelik, Gürsoy Alagöz}

Sakarya Üniversitesi Eğitim ve Araştırma Hastanesi, Göz Hastalıkları Kliniği, Sakarya

Yazışma Adresi / Correspondence:

\section{Özlem Bursalı}

Kemalpaşa Mah.38.Sk No25 Yakamoz Konakları Serdivan/SAKARYA

T: +90 $5063779575 \quad$ E-mail: drozlemtas@yahoo.com

Geliş Tarihi / Received : 26.03.2018 Kabul Tarihi / Accepted : 24.04.2018

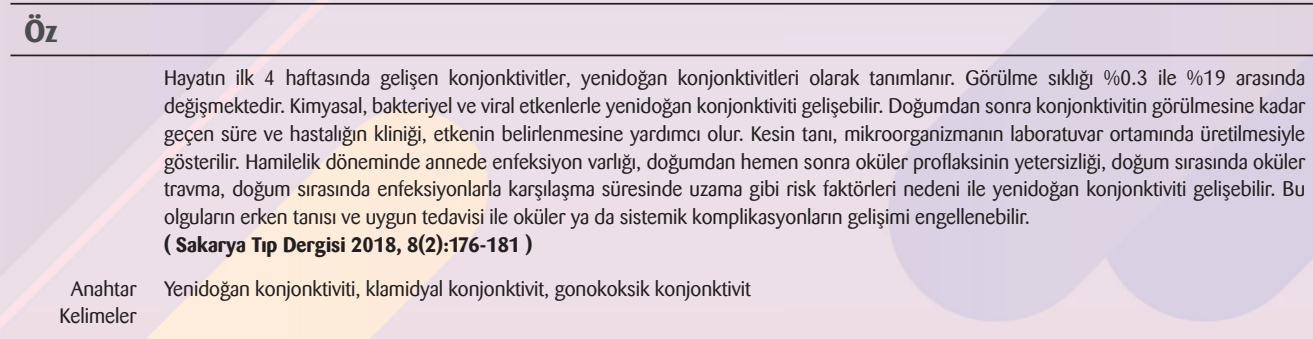

\section{Abstract}

Acute conjunctivitis occurring in the first 4 weeks of life, is named as neonatal conjunctivitis. Prevelance of neonatal conjunctivitis ranges from $\% 0.3$ to $\% 19$. Chemical, bacterial and viral pathogens can cause neonatal conjunctivitis. The time interval after birth to the onset of conjunctivitis and the clinical findings may help to determine the causative agents. The certain diagnosis must include isolation of the pathogens by laboratory studies. Risc factors such as the presence of infection at pregnancy, the deficiency of ocular prophylaxis after birth and ocular trauma during birth may cause conjunctivitis of the newborn. Early dignosis and and appropriate treatment prevents ocular and systemic complications ( Sakarya Med J, 2018, 8(2):176-181 ).

Key Words Neonatal conjunctivitis, gonococcal conjunctivitis,chlamydial conjunctivitis 
Sakarya Tip Dergisi 2018;8(2):176-181

\section{Giriş}

Hayatın ilk 4 haftasında gelişen konjonktivitelerini ilk kez Quellmalz, ophthalmia neonatorum olarak tanımlamış, daha sonra Dünya Sağık Örgütü tarafından yenidoğan konjonktivitleri (YK) olarak adlandırılmıştır. ${ }^{1}$ YK, bakteriyel ve viral etkenlerle gelişebileceği gibi konjonktivit proflaksisinde kullanılan kimyasal ajanlara bağlı olarak da gelişebilir. YK görülme sıklığı, farkı çalışmalarda \%0.3 ile $\% 19$ arasında bildirilmiştir. ${ }^{2}$

Gözyaşında bulunan lizozimler, immunoglobulinler, komplemanlar, antibakteriyel enzimler sayesinde sağlıklı yenidoğan oküler yüzeyi, kendine özel anatomik ve fonksiyonel özellikleri ile bakteriyel patojenlere karşı korunaklıdır. Gözyaşının tüm bu olumlu özelliklerine rağmen; annenin doğum kanalında yerleşen mikroorganizmalar, hamilelik döneminde annede enfeksiyon varlığı, doğumdan hemen sonra oküler proflaksinin yetersizliği, doğum sırasında oküler travma, doğum sırasında enfeksiyonlarla karşlaşma süresinde uzama gibi risk faktörleri nedeni ile YK gelişebilir., ${ }^{2,3}$

Doğum sonrasından konjonktivit gelişimine kadar geçen süre, etyolojinin belirlenmesinde önemli bir yardımcıdır. İlk birkaç saat içinde gelişen YK, genellikle gümüş nitratın kimyasal etkisi nedeni ile gelişir. Gonokoksik enfeksiyonlar sıklıkla 2-4 gün içerisinde ortaya çıkarken, klamidyal enfeksiyonlar 5-14 gün içerisinde gelişirler. Herpes simplekse ikincil YK'ler ise 5-7 gün içerisinde ortaya çıkmaktadırlar. ${ }^{2}$

\section{Proflaksi:}

Gonokokkal konjonktivite bağlı keratitler, 19.yüzyılda, yenidoğanlardaki en büyük körlük sebebini oluşturuyordu. Alman doğum uzmanı Carl S.F. Crede'nin 1881 yilında yenidoğanlarda, proflaktik olarak \%2'lik gümüş nitrat kullanımını getirmesiyle YK ve körlük gelişimi önemli ölçüde azalmıştır. ${ }^{4}$ Gümüş nitrat proflaksisi, oldukça geniş antimikrobiyal spektruma sahip olmasına rağmen, C.Trachomatis'e karşı sınırlı etkiye sahip olması ve kendisinin kimyasal konjonktivite yol açması nedeniyle diğer ajanların kullanımını gündeme getirmiştir.

Isenberg ve ark. povidon iyodin kullanımının oldukça ucuz ve etkili bir yöntem olduğunu göstermişlerdir. Povidon-iyodinin \%0.1'lik konsantrasyonunun Neisseria gonorrhoeae'ye; \%1'lik konsantrasyonunun Chlamimdya trachomatis'e;5 \%0.5'lik konsantrasyonunun ise Human Immunodeficiency Virus (HIV) ve Herpes simpleks virüs (HSV) gibi virüslere etkili olduğu gösterilmiştir. ${ }^{5,6}$ $\% 1$ gümüş nitrat ve $\% 0.5$ eritromisinle karşılaştııııdığında, \%2.5'luk povidon-iyodinin, konjonktival bakterilere karşı daha etkili olduğu; gümüş nitrata göre ise daha az toksik olduğu gösterilmiştir.? Doğumdan hemen sonra bir kez damlatılan povidon iyodine ek olarak, doğumdan sonraki 1.günde ikinci kez uygulamanın kapak ödemini artırdığı ve hiçbir ek avantajı olmadığı gösterilmiştir. ${ }^{4}$

İran'da 330 yenidoğanın üç eşit gruba ayrılarak planlanan bir çalışmada; klinik olarak konjonktivit görülme oranı povidon iyodin damlatılan grupta $\% 9$, eritromisin damlatılan grupta $\% 18.4$ ve tedavi almayan grupta \%22.4 olarak saptanmıştır.8 YK proflaksisinde tobramisin, gentamisin ve tetrasiklin diğer kullanılan ajanlardandır. ${ }^{1}$ Binenbaum ve arkadaşları, yenidoğanda profilaktik olarak kullanılan gentamisinin perioküler ülseratif dermatit yaptı̆ı̆ını bildirmişlerdir. ${ }^{9}$ Yurt dışında kullanılan eritromisin göz pomadı ülkemizde bulunmadığından, yerine azitromisin damla kullanımı iyi bir alternatif olabilir. Ayrıca fusidik asit de N. Gonorrhoeae ve C. Trahomatis'e etkili olması nedeniyle YK profilaksisinde kullanılabilir. 
Türkiye genelinde, 24 üniversite ve 24 devlet hastanesinin katıldığı bir anket çalışmasına göre YK profilaksi uygulama oranı $\% 58.3$ oranında bulunmuştur. Bu oran üniversite hastanelerinde $\% 66.7$, devlet hastanelerinde ise $\% 50$ olarak bulunmuştur. Aynı araştırmada, proflakside en sık kullanılan iki ilacın gentamisin (\%64.3) ve tobramisin (\%8.3) olduğu saptanmıştı. ${ }^{10}$

\section{Kimyasal Konjonktivit:}

YK proflaksisinde kullanılan ilaçlara bağlı kimyasal konjonktivit gelişebilir. Ilaç uygulandıktan sonra birkaç saat içinde konjonktival hiperemi ve sulanma başlar. Bu durum genellikle 24-36 saat içinde tedavi gerektirmeden kendiliğinden iyileşir. Isenberg'in yaptığı bir çalışmada \%2.5'luk povidon iyodin $\% 9.7, \% 0.5^{\prime}$ lik eritromisinin $\% 13.3$ ve $\% 1$ 'lik gümüş nitratın $\% 13.9$ oranında kimyasal konjonktivite yol açtığı gösterilmiştir. ${ }^{1}$ Gümüş nitrat, epitel hücrelerine hasar vererek, diğer enfektif ajanlara karşı gözü daha hassas hale getirebilmektedir. ${ }^{3}$

\section{Klamidyal Konjonktivitler:}

Crede'nin gümüş nitrat proflaksisi kullanılmaya başlandıktan sonra, klamidyal etkinliği sınırlı olduğundan klamidyal konjonktivit olguları artmıştır. Günümüzde de klamidyal konjonktivitler en sık YK etkenidir. ${ }^{10,11}$ İnsidansı 1000 canlı doğumda 0.78 ile 8 arasında değişmektedir. ${ }^{12-14}$

Klamidyal genital enfeksiyon, hamile kadınların \%5-30'unda görülmektedir. Tedavi edilmemiş aktif genital enfeksiyonu olan annelerin bebeklerinde \%30-50 oranında klinik olarak konjonktivit gözlenir. ${ }^{15}$ Enfeksiyon, genellikle normal doğum sırasında doğum kanalından bulaşır. Erken membran rüptürü olan olgularda nadiren, sezaryen sonrası da gelişebilir.

Klamidyal konjonktivit genellikle doğumdan 5-14 gün sonra, tek veya çift taraflı olarak başlar. Kapak ödemi, papiller konjonktival reaksiyon ve psödomembran gelişimi görülebilir. Yenidoğanda konjonktival lenfoid dokunun ilk 3 aydan önce gelişmemesi nedeni ile foliküller izlenmez. Enfeksiyonun erken döneminde seröz kıvamda olan sekresyon, ilerleyen dönemlerde mükopürülan ya da kanlı bir hale dönüşür (Resim 1). Hastalık, kendini sınırlayabilse de ağır olgularda konjonktival skarlaşma, periferik korneada pannus ile korneada skarlaşma ile seyredebilir. Topikal tetrasiklin, sulfasetamid ya da eritromisin, konjonktival ve korneal komplikasyonların gelişme riskini azaltır.

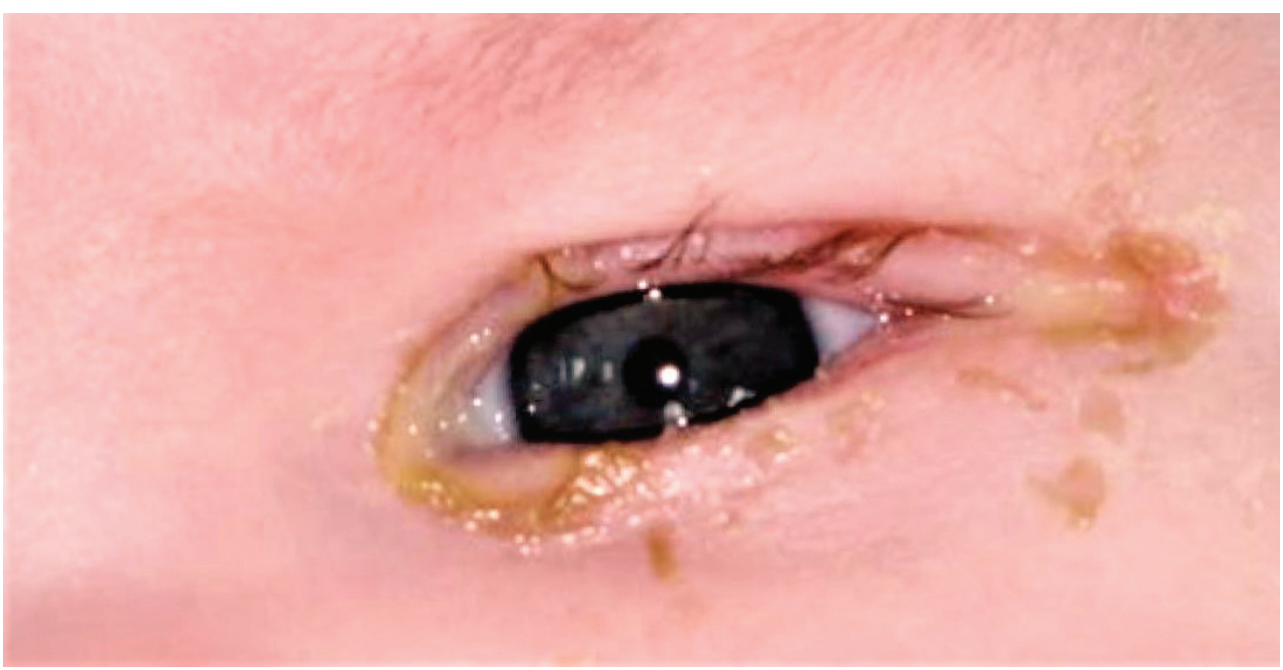

Resim 1. Klamidya enfeksiyonuna ikincil yenidoğan konjuktiviti olgusu
Sakarya Tip Dergisi 2018;8(2):176-181

BURSALI ve Ark Yenidoğan Konjonktivit 
Sakarya Tip Dergisi 2018;8(2):176-181

Konjonktival sürüntü örneklerinin Giemsa boyaması ile polimorfonükleer lökositler ve bazofilik intrastoplazmik inklüzyon cisimleri içeren epitelyum hücrelerin görülmesi ile tanı konur. Kültürde üreme, PZR (polimeraz zincir reaksiyonu), direkt floresan antikor testi ve enzim immunoassay yöntemleri ile de tanı konabilir. Özellikle kliniği hafif olan olgularda, klasik yöntemlere göre duyarlılığı daha yüksek olan PZR testi tanıda çok değerlidir.

Klamidyal konjonktivit gelişimini önlemedeki en etkili yöntem, gebelikte prenatal klamidya enfeksiyonunun tarama ve tedavisinin yapılmasıdır.

\section{Gonokokkal konjonktivitler:}

Yüzyıl önce neonatal konjonktivitin en sık sebebiydi. Son yıllarda proflaksi nedeniyle insidansı 1000 'de 0.3 oranındadır. N. Gonorrhoeae sağlam epiteli geçebilen gram negatif bir diplokoktur. Virulansı en yüksek YK etkenidir.

Tipik olarak ilk 24-48 saat sonra belirti verir. Kemozis, konjonktival membran, pseudomembran ve akut pürülan sekresyon bulguları arasındadır. Göz kapakları, altında enfeksiyöz sıvı birikimi nedeniyle sert ve ödemlidir. Kapakların açılmasıyla, pürülan sekresyon fışkırabilir. Sekresyon temizlense bile hemen tekrar oluşabilir. Sağlam kornea epitelinden geçebildiği için, korneal ülserasyon ve endoftalmi yapabilir. Bu yüzden erken tanı ve tedavi çok önemlidir. Bilateral enfeksiyon sıktır. ${ }^{12}$ Tanı, konjonktiva sürüntülerinde gram negatif hücre içi diplokokların görülmesiyle konur. 37 derecede $\% 10$ karbon dioksit ortamında inkübe edilen çikolata agar veya Thayer-Martin besiyerinde kültüre edilir.

Penisilinin ticari damla ve pomad formu olmadığından, tedavi için 10.000-20.000 Ü/ml olacak şekilde penisilin G damla hazırlanır. Topikal penisilin G önce yarım saat içinde 5 dakikada bir yükleme dozu ile başlanır; sonra saat başı damla ile devam edilir. Sistemik olarak ise intravenöz aköz penisilin G 100.000 Ü/kg/gün dört doz halinde ya da benzatin penisilin 50.000 Ü/kg/gün 7 gün uygulanır. Penisiline dirençli suşların artması nedeniyle, sefotaksim $(50 \mathrm{mg} / \mathrm{kg} /$ gün, günde iki kez oral veya $100 \mathrm{mg} / \mathrm{kg} /$ gün intravenöz tek doz) verilebilir. Seftriakson verilecekse $25-50$ mg/kg/gün (maksimum total doz $125 \mathrm{mg}$ ) tek doz, 7 gün süreyle verilebilir. Tedaviye yanıt vermeyen olgularda Klamidya akla getirilmelidir. ${ }^{3}$

\section{Diğer Bakteriyel Enfeksiyonlar:}

YK'ye sebep olan bakterilerden, Stafilokokus aureus, Streptokokus pneumonia, Streptokokus viridans ve Stafilokokus epidermidis gram pozitif bakterilerdendir. Gram negatif bakterilerden ise Haemophilus influenza, Escherischa coli, Proteuslar, Enterobakteriler, Klebsiella pneumoniae ve Serratia marcescens sayılabilir. Bazı çalışmalarda S.epidermis, bazılarında ise S.aureus en sık et- 
ken olarak bulunabilir. ${ }^{18}$ Bu bakteriyel konjonktivitler, tipik olarak 2-5 gün sonra ortaya çıksa da, herhangi bir zamanda görülebilirler. Kapak ödemi, konjonktival hiperemi ve pürülan sekresyon bulgular arasındadır.

Bakteriyel YK'li olgularda, \%1 fusidik asit 2x1 ve \%0.5 kloramfenikol 6x1 kullanımının etkili olduğu gösterilmiştir. ${ }^{19}$ Gram pozitifler için \%0.5 eritromisin pomad (ülkemizde bulunmamaktadır), gram negatifler için topikal gentamisin veya tobramisin kullanılabilir. Sadece yenidoğanları kapsamayan fakat toplam 150'si term yenidoğan ve çocuk olan 1000'den fazla bakteriyel konjonktivitli olguyu içeren bir çalışmada, \%1.5'luk azitromisin damla $2 \times 1,3$ gün süreyle kullanıldığında, tobramisin ile karşılaştıııldığında bakteriyel kür açısından anlamlı fark bulunamadığı gösterilmiştir. ${ }^{20}$

\section{Viral Konjonktivitler:}

Herpes virüs tip 1 ve 2 ile konjonktivit gelişebilir. Genital herpes enfeksiyonlarının artmasıyla, HSV tip 2'ye bağlı konjonktivit daha sık görülmektedir. HSV tip 1 ise dudağında uçuk olan birinin öpmesiyle geçebilir. Doğum sonrası genellikle iki hafta içinde semptom verir. Göz kapaklarında ödem, kapak kenarlarında ve vücutta veziküller görülebilir. Epitelyal ve stromal keratit, keratoüveit, vitritis, retina dekolmanı, katarakt, koryoretinit ve optik nörit gelişebilecek göz komplikasyonları arasında sayılabilir. Pnömoni, septisemi ve menenjit gibi ciddi sistemik komplikasyonlar da eşlik edebilir.

Tanı, konjonktiva sürüntülerinde ve vezikül sıvısında eozinofilik intranükleer inklüzyonların ve çok nükleuslu dev hücrelerin görülmesiyle konur.12 Viral kültür ve monoklonal antikor immunassayi ile tanı doğrulanır.

Tedavide 2 saatte 1 triflorotimidin damla ya da asiklovir pomad $5^{*} 1$ şeklinde kullanılabilir. Sistemik komplikasyonlar sistemik asiklovir ile tedavi edilir. En etkili tedavi, genital herpesi bilinen anneden sık kültür alarak ve gerektiğinde tedavisi yapılarak, hastalık önlendiğinde yapıımış olur. ${ }^{3}$ 
1. Isenberg SJ, Apt L, Wood M. A controlled trial of povidone-iodine as prophylaxis against ophthalmia neonatorum. N Engl J Med. 1995;332(9):562-6.

2. Zuppa AA, D'andrea V, Catenazzi P, et al. Ophthalmia neonatorum: what kind of prophylaxis? J Matern Fetal Neonatal Med. 2011;24(6):769-73.

3. Rubenstein JB. Konjonktiva ve limbus hastalıkları, in Ophthalmology. Yanoff M. Editor 2004;403-404.

4. Simon JW. Povidone-iodine prophylaxis of ophthalmia neonatorum. $\mathrm{Br}$ J Ophthalmol. 2003;87(12):1437.

Sakarya Tıp Dergisi

2018;8(2):176-181

BURSALI ve Ark

Yenidogan

Konjonktivitler
5. Benevento WJ, Murray P, Reed CA, et al. The sensitivity of Neisseria gonorrhoeae, Chlamydia trachomatis, and herpes simplex type II to disinfection with povidone-iodine. Am J Ophthalmol. 1990;109(3):329-33.

6. Harbison MA, Hammer SM. Inactivation of human immunodeficiency virus by Betadine products and chlorhexidine. J Acquir Immune Defic Syndr. 1989;2(1):16-20.

7. Isenberg SJ, Apt L, Yoshimori R, et al. Povidone-iodine for ophthalmia neonatorum prophylaxis. Am J Ophthalmol. 1994;118(6):701-6.

8. Ali Z, Khadije D, Elahe A, et al. Prophylaxis of ophthalmia neonatorun comparison of betadine, erythromycin and no prophylaxis. J Trop Pediatr. 2007;53(6):388-92

9. Binenbaum G, Bruno CJ, Forbes BJ, et al. Periocular ulcerative dermatitis associated with gentamicin ointment prophylaxis in newborns. Pediatr. 2010;156(2):320-1.

10. Eser I. A nationwide survey of prophylaxis against ophthalmia neoma torum in Turkey. Turk J Med Sci. 2009;39(5):771-774.

11. Kakar S, Bhalla P, Maria A, et al. Chlamydia trachomatis causing neonatal conjunctivitis in a tertiary care center. Indian J Med Microbiol. 2010;28(1):45-7.
12. Hosal BM. Yenidoğan Konjonktiviti. Turkiye Klinikleri J Ophthalmol-special Topics. 2012;5(2):37-40

13. Hammerschlag MR. Chlamydial and gonococcal infections in infants and children. Clin Infect Dis. 2011;53(3):99-102

14. Yip TP, Chan WH, Yip KT, et al. Incidence of neonatal chlamydia conjunctivitis and its association with nasopharyngeal colonisation in a Hong Kong hospital, assessed by polymerase chain reaction. Hong Kong Med J. 2007;13(1):22-6.

15. Schachter J, Grossman M, Sweet RL, et al. Prospective study of perinata transmission of Chlamydia trachomatis. JAMA. 1986;255(24):3374-7.

16. Hammerschlag MR, Chandler JW, Alexander ER, et al. Longitudinal studies on chlamydial infections in the first year of life. Pediatr Infect Dis. 1982;1(6):395-401

17. Hammerschlag MR, Gelling M, Roblin PM, et al. Treatment of neonatal chlamydial conjunctivitis with azithromycin. Pediatr Infect Dis J. 1998;17(11): 1049-50.

18. Wadhwani M, D'souza $P$, Jain $R$, et al. Conjunctivitis in the newborn- a comparative study. Indian J Pathol Microbiol. 2011;54(2):254-7.

19. Normann EK, Bakken O, Peltola J, et al. Treatment of acute neonatal bacterial conjunctivitis: a comparison of fucidic acid to chloramphenicol eye drops. Acta Ophthalmol Scand. 2002;80(2):183-7.

20. Bremond-Gignac D, Mariani-Kurkdjian P, Beresniak A, et al. Efficacy and safety of azithromycin $1.5 \%$ eye drops for purulent bacterial conjunctivitis in pediatric patients. Pediatr Infect Dis J. 2010;29(3):222-6. 